\title{
GERABA Android-Based Application to Facilitate the Students of TK Tarbiyatul Athfal Al-Falach Malang on Memorizing the Prayer Movements and Reading
}

\author{
Grezi Bimbi Mandira \\ Faculty of Education Science \\ State University of Malang \\ Malang, Indonesia \\ grezibmandira@gmail.com
}

\author{
Muhammad Andri Wicaksono \\ Faculty of Education Science \\ State University of Malang \\ Malang, Indonesia \\ andrywicaksono26@gmail.com
}

\author{
Dyna Sumda Aswad \\ Faculty of Education Science \\ State University of Malang \\ Malang, Indonesia \\ sumdadyna@gmail.com
}

\begin{abstract}
Teaching worship to children is not an easy job. In kindergarten institution, there is a habit before students and teachers begin their learning, they must apply the system of memorizing the prayer movements and reading. Therefore it takes a community service effort to provide solutions for teachers in kindergarten in the form of android based application that can support the ability of children. This application is named Geraba (Movement of Prayer and Reading) which helps children to understand and apply the daily prayer movement easily. Methods of implementation include (1) the preparation phase, (2) activity Implementation, (3) and evaluation. The results obtained are changing the pattern of memorization in TK Tarbiyatul Athfal Al-Falach Malang and the realization of Geraba program (movement of prayer and reading) to the children of Tarbiyatul Athfal AlFalach Kindergarten Malang to help children memorize the prayer movement and reading.
\end{abstract}

Keywords-android application, memory, reading, kindergarten

\section{INTRODUCTION}

Teaching worship in children is not easy to do. Childhood boredom and difficulty are an indication of comfort when learning [1]. Discomfort learning will construct the child feeling lazy to do it again [2] . Learning requires maturity in the child's brain, and among one child with another child different maturity time. A child who has matured his brain is able to understand well at the age of 3 years, so it is not hard to memorize it, but there is also a new ready when the age of 7 years.

The key to learning success is the ability to construct and manage information in the brain [3]. According to the age of 2-7 years, the child's cognitive development is included in the preoperative stage [4]. At this stage, the children can do something as a result of imitating or observing something behavioral model and able to perform the symbolization. The application needed is to describe how the real movement and also the reading then the child will quickly catch than just memorize it without any real example.

Knowledge of information technology has become a must-fulfill requirement right now [5]. This is because most of the daily activities of a person involve the help of information technology in teaching and learning activities. Application learning is a medium that can be used to convey material content involving mobile devices such as mobile phones, laptops, and tablet PCs [6]. Given the importance of memorizing prayers and movements for human life, it should be when children learn it from an early age.

TK Tarbiyatul Athfal "Al-Falach" Malang is one of kindergarten located in Ikan Tombro Tengah Sawah street, Tunjung Sekar, Lowokwaru, Malang. This kindergarten has 3 classes each class containing 20 children so the total of children who attend school here about 60 children who follow education. In kindergarten, there is a habit before the lesson begins that is they apply the system of memorizing the morning prayer readings. The problem that often arises that children are difficult to memorize because memorizing activities for children is a boring thing. In addition to difficult to memorize the children automatically will be difficult to apply because it does not see directly the movement of prayer.

The Student Creativity Program "Geraba" (Prayer and Reading Movement) provides solutions to learning problems. Android-Based Education Application To Facilitate Kindergarten Children Tarbiyatul Athfal Al-Falach Malang Memorizing Prayer and Reading Movements". In kindergarten Tarbiyatul Athfal Al-Falach Malang needs an effort to change learning through community service in order to provide solutions to teachers in kindergarten is an application that can support the ability of children and that application is Geraba. The constructed solution is to make it easier to understand and apply the daily prayer movement. In the era of all sophisticated as now required tools or applications that can be used to facilitate children in learning [7].

The traditional learning model is felt less to overcome the problems in learning (here related to the learning material of prayer movement and reading) it is necessary to have an application to facilitate students learning TK Tarbiyatul Athfal Al-Falach Malang to easily memorize the prayer movement and also the reading. The expected expenditure of this program of devotion aims to introduce the application program Geraba (Movement of Prayer and Reading) to the children of Tarbiyatul Athfal Kindergarten AlFalach Malang as well as guiding the children so they can learn about the prayer movement and its readings and can apply it, but also guide the children to use this application so as not to be mistaken, because children of that age will have difficulty using before they are guided. 


\section{Method}

The overall implementation method includes socialization, (2) Introduction, (3) Implementation, (4) Assistance, (5) Evaluation (figure 1). Socialization of the program is done by providing training sight to teachers who teach in kindergarten Tarbiyatul Athfal Al-Falach Malang. Socialization is done to equate perceptions about the purpose of the utilization of the program. Sosisalisasi did in order to provide knowledge and skills of teachers to provide assistance to children in kindergarten Tarbiyatul Athfal AlFalach Malang.

The introduction of Geraba was done to all the children in TK Tarbiyatul Athfal Al-Falach Malang. The introduction is based on the characteristics of children as learners. The introduction is a way of building pre-operational thinking in children. Introduction activity is the first way to get closer to the design with the implementation of Geraba program.

Implementation is done after the children feel comfortable in learning. Implementation is done after getting a picture of the ability of children in using AndroidBased Education Application to Facilitate Children Kindergarten Tarbiyatul Athfal Al-Falach Malang Memorizing Prayer and Reading Movements. At the stage of application of children trained use as well as practice memorization and reading.

Technical assistance is an effort to see the difficulties that occur in the use of Android-based education applications in children in kindergarten Tarbiyatul Athfal Al-Falach Malang. The difficulty, in general, is an adaptation of the learning environment to the electronic interface.

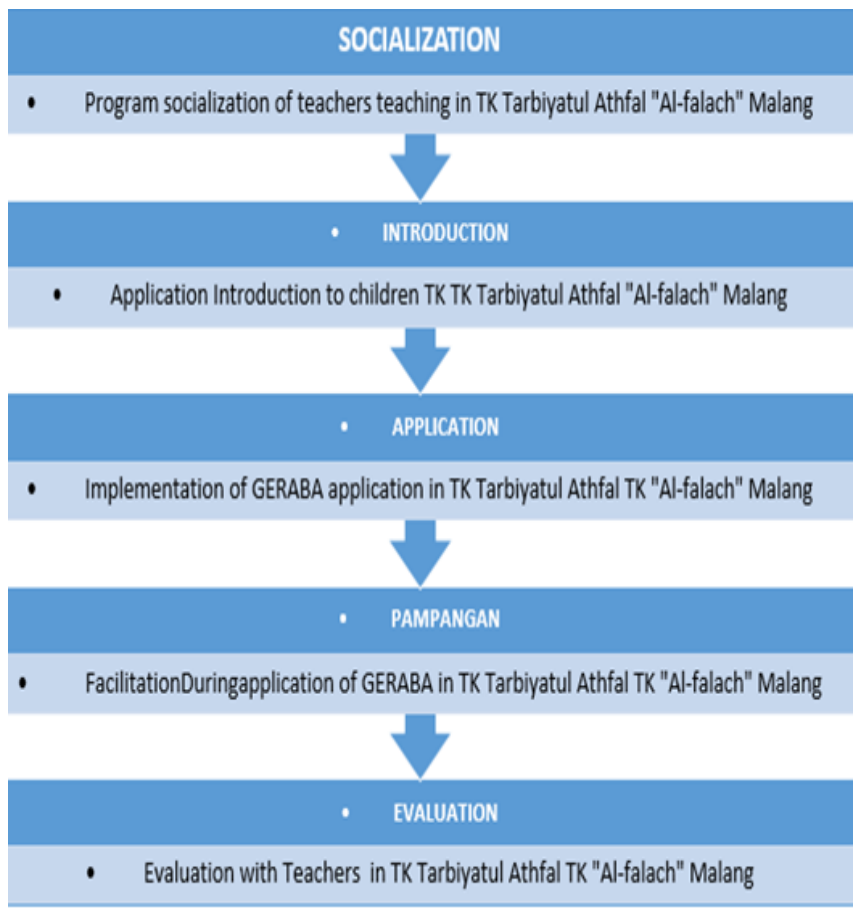

Fig. 1. The Method of Geraba Activity

Evaluation is done in order to see the android-based educational application to facilitate Children Kindergarten Tarbiyatul Athfal Al-Falach Malang in memorizing the Prayer movement and reading. Evaluation is to see the effectiveness, efficiency, and attractiveness as the basis for justifying the program

The overall method used is the implementation of the Student Creativity Program entitled "Geraba (Prayer Movement and Reading) educational applications based on android to facilitate children kindergarten Tarbiyatul Athfal Al-Falach Malang to memorize the prayer movement and reading. The program is an application, grant handling module, application usage, and mentoring and evaluation.

\section{RESULT AND IMPLEMENTATION}

Application development is an application design process. Figure 2 is a design that describes the religious aspect that is packaged in the construction of a child's character. Reinforcement is also a religious to establish the identity of the program [8].

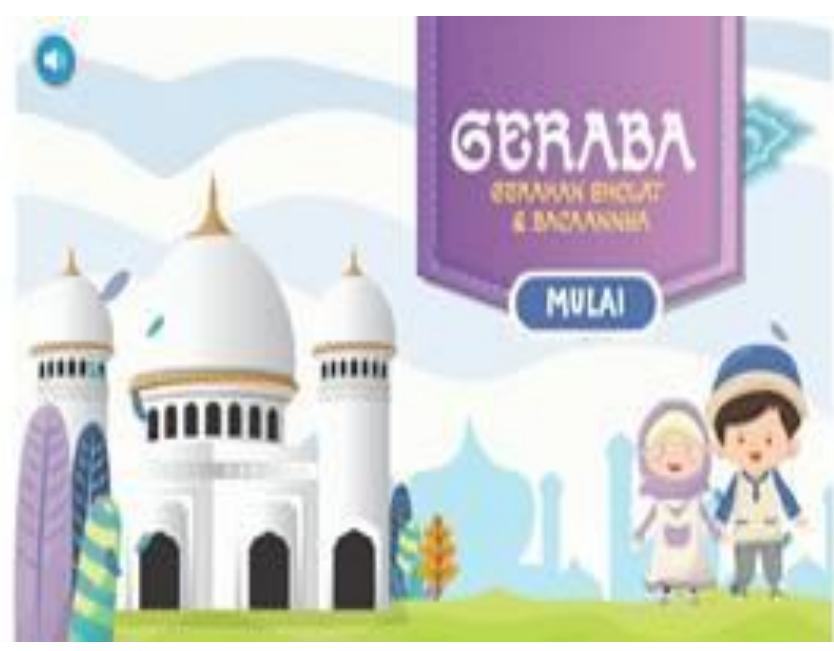

Fig. 2. The Initial Application of Geraba

Figure 3 is the main menu display that gives symbolic nuance. Symbolic nuance intended to communicate the message in the form of graphics [9].

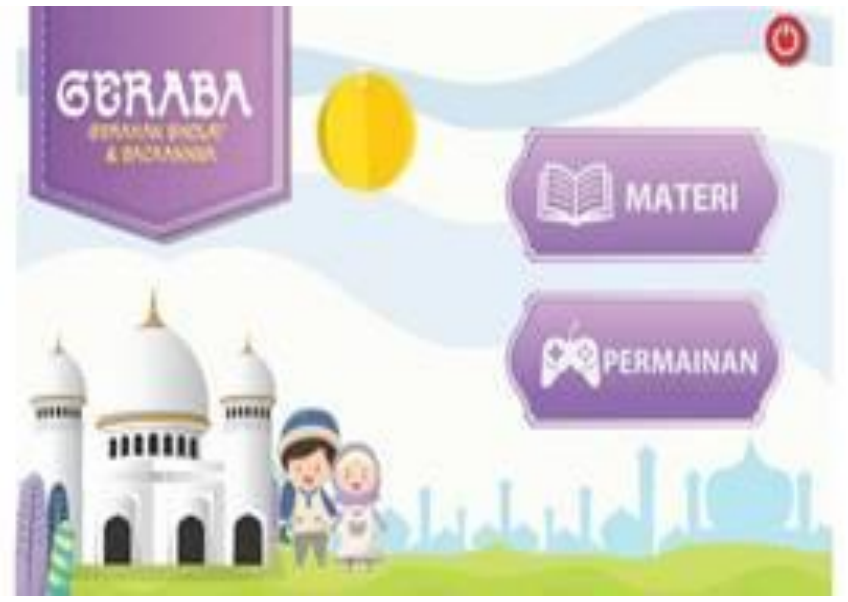

Fig. 3. The Main Menu of Geraba Program

Figure 4 is a submenu developed through symbolic with category reinforcement. Reinforcement of categories is done to visually communicate that in symbolic icons have different meanings [10]. 


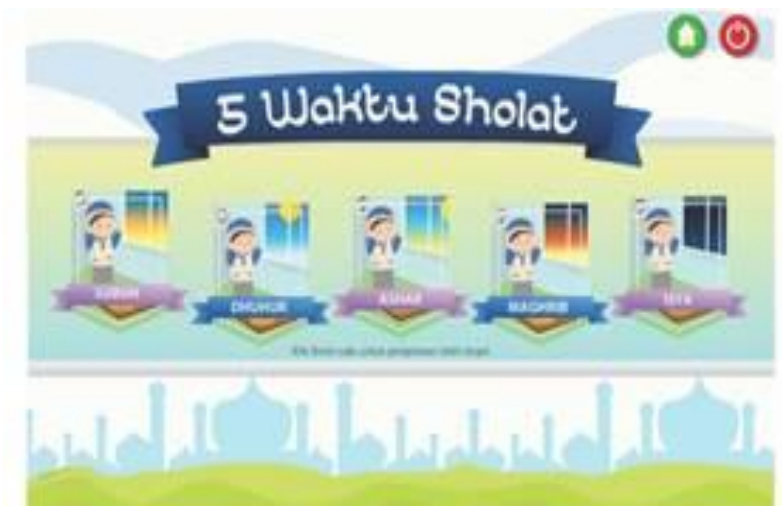

Fig. 4. The Submenu of Geraba Application

In Figure 4 the gamification is done. Cognitive reinforcement requires specific reinforcement for information that children have acquired easily [11].

The program is technically started from the socialization of the program intended to Teachers in Tarbiyatul Athfal Kindergarten Al-Falach Malang can recognize and understand the program flow in the PKM we have designed. In addition, this socialization also held a discussion forum about the problems and expectations that had been faced by the kindergarten teacher Tarbiyatul Athfal relation with learning prayer (movement and the text). The discussion did to strengthen the ability to no longer dominate and become a partial program [12]. The discussion was carried out by the PKM team and teachers as Geraba media users. From the results of this discussion, the PKM team explained the steps to use Geraba media in accordance with the slideshow even though the application will still be accompanied by the PKM team.

After that the introduction of the application to children kindergarten Tarbiyatul Athfal Al-Falach Malang. Introduction of this application is addressed to children kindergarten Tarbiyatul Athfal Al-Falach Malang Memorizing Prayer and Reading Movement. The stages of introducing the application and telling of the purpose are accompanied by the teacher after they understand the new application shown and teach how to use it. Students are introduced to the purpose, content, and steps in using the Geraba application. Students are also used to provide questions and discuss when introducing the Geraba application.

The implementation is still in the assistant teacher and also PKM team who supervise and teach in case of distress. Here children should be able to memorize the prayer movement and reading it at once. They knew how to simulate the movement of prayer and the reading so as not to be confused. Example, the movement, and reading of Takbiratull Ikhram. The final stage is the evaluation of teachers in TK Tarbiyatul Athfal Al-Falach Malang conducted to know the weaknesses and advantages ranging from the introduction, process, result, and impact of Geraba Movement of Prayer and Reading Based Education Application Android to Simplify Children Kindergarten Tarbiyatul Athfal Al-Falach Malang.

Based on the results of the implementation of Geraba it can be seen that students can be trained to memorize the prays and reading movements more easily. Students enthusiastically learn to use Geraba's media so students feel happy and interested in memorizing prayer movements and reading. Students can memorize prayers according to the stages on Geraba's media slides and help teachers to teach students. At each stage, socialization, discussion, introduction, implementation, and evaluation showed that the Geraba Movement of Prayer and Reading Based Android Education Application for Simplifying Children Kindergarten Tarbiyatul Athfal Al-Falach Malang can be applied in schools.

\section{Conclusion}

The Geraba program (Prayer Movement and reading) is an android-based educational app that is used to make it easier for children to memorize movements and prayer readings. The purpose is to facilitate the learning of kindergarten student Tarbiyatul Athfal Al-Falach Malang to easily memorize the prayer movement and also the reading. Targets include the creation of a Geraba application program which will then be introduced to the kindergarten children Tarbiyatul Athfal Al-Falach Malang and guide the children in order to learn the movement of prayers and readings and can apply it, but it also guides the children to be able to use this application to make no mistake, because children of that age will have difficulty using before they are guided. In addition, this activity also helps teachers in solving problems in learning. This program is also a media that can be used for extension workers to increase experience and transfer of science that have been obtained from universities.

\section{ACKNOWLEDGMENT}

With the completion of this scientific article, the authors say thanks to KEMENRISTEKDIKTI, as a funder in our PKM program so that it can be done. And the State University of Malang and Tarbiyatul Athfal Al-Falach Malang as an institution where conducting program activities.

\section{REFERENCES}

[1] Praherdhiono. H, "Convenience of Learning Environment for Student Special Education With Cyberwellness Concept". Proceeding International Postgraduate Program University Kebangsaan Malaysia. SEAMOSEN, 2014.

[2] Praherdhiono. Henry, "Standar Program Pengukuran Kenyamanan Lingkungan Belajar Berbasis Ergonomi". Dissertation and Thesis Postgraduate Program The Learning University, 2016.

[3] Davey. J. D, "A Theoretical Model Of Learning Employing Constructivism, Neuroscience, And Phenomenology: Constructivist Neurophenomenology". Southern Illinois: University at Carbondale, 2011.

[4] Piaget. J, "The Construction Of Reality In The Child". New York: Routledge, 2013.

[5] Hong. K S, and Songan. P, "ICT In The Changing Landscape Of Higher Education In Southeast Asia". Australasian Journal of Educational Technology, vol. 27(8), https://doi.org/10.14742/ajet.893.

[6] Praherdhiono. H, and Pramono. Adi E, "Constructing Learning Results as Learning Object Through Open Learning System". Atlantis Press, 2017, https://doi.org/10.2991/icet-17.2017.52.

[7] Praherdhiono. Henry, Sulton M, Lioe. A T, and Hammad. J, "Open Learning Systems for Learners with Capabilities as Innovators at State University of Malang". Atlantis Press, 2018, https://doi.org/10.2991/icli-17.2018.36.

[8] Kim. H K, and Bateman. B, "Student Characteristics And Participation Patterns In Online Discussion". International Conference 
of Society for Information Technology \& Teacher Education, vol. 2007, 2017, pp. 2381-2387.

[9] Graf. S, and Liu. T C. "Analysis Of Learners' Navigational Behaviour And Their Learning Styles In An Online Course". Journal of Computer Assisted Learning, 26(2), 2010, pp.116-131.

[10] Mayer. R E, Heiser. J, and Lonn. S, "Cognitive Constraints On Multimedia Learning: When Presenting More Material Results In Less Understanding". Journal of Educational Psychology, 93(1), 2011, pp. 180-187.
[11] De-Marcos. L, Domínguez. A, Saenz-de-Navarrete. J, and Pagés. C, "An Empirical Study Comparing Gamification And Social Networking On E-Learning". Computers \& Education, 75, 2014, pp. 82-91.

[12] Siemens. G, "Learning And Knowing In Networks: Changing Roles For Educators And Designers". ITFORUM for Discussion, 2008, pp. $1-26$. 